\title{
Assessment of Environmental Factors on Growth of Brinjal under Open and Protected Conditions
}

\author{
E. Shikha*, M. Kunnathadi, K. Shahida, S. Sreelekshmi and E. Jubail \\ Agricultural Research Station, Anakkayam, Anakkayam P. O, \\ Malappuram- 676505, Kerala, India \\ *Corresponding author
}

\section{A B S T R A C T}

\begin{tabular}{l} 
K e y w o r d s \\
Brinjal, Polyhouse, \\
Open field, \\
Environmental \\
factors, Climate \\
change, \\
Temperature, \\
Humidity, Leaf area \\
index \\
\hline Article Info \\
$\begin{array}{l}\text { Accepted: } \\
\text { 04 March } 2020 \\
\text { Available Online: } \\
\text { 10 April } 2020\end{array}$ \\
\hline
\end{tabular}

The present study was undertaken at Agriculture Research Station, Anakkayam from February- April, 2019 with objectives to study the influence of various environmental conditions on growth of brinjal (Solanum melongena) under protected and open cultivation and to analyze the impact of variations in temperature, humidity and soil moisture on plant biometric characters. The abiotic factors like temperature, humidity and soil moisture showed significant variation under different growing conditions (open field and polyhouse). Mean daily temperature $\left(36.9^{\circ} \mathrm{c}\right)$ and relative humidity $(66 \%)$ were higher under polyhouse as compared to open field values of $31.72^{\circ} \mathrm{c}$ and $47.5 \%$ respectively. The biometric characters such as plant height, number of leaves, leaf area index, fruit length, girth and weight were also recorded. Plants grown in polyhouse had higher plant height $(44.4 \mathrm{~cm})$ and leaf area index (1.091) as compared to open field. The mean fruit weight was observed to be $106.6 \mathrm{~g}$ under polyhouse open field $(78.32 \mathrm{~g})$. The study showed that high temperature combined with optimum relative humidity was favourable for the growth of brinjal plants under protected condition and that had a positive correlation on plant biometric and yield parameters. High moisture per cent along with microbial diversity of soil under protected condition also had a significant role in improving soil fertility, which in turn favoured growth and productivity of the crop.

\section{Introduction}

Vegetables are important component of balanced human diet. Brinjal or eggplant (Solanum melongena) is one of the most common tropical vegetable crops. It is a versatile crop adapted to different agroclimatic regions. Large number of varieties with different fruit size, shape and color are grown in India. Fruits are moderate source of vitamins and minerals like phosphorous, calcium and iron. The nutritive value of fruits varies from variety to variety. Wild relatives of brinjal have shown to be an important source for transferring tolerance to biotic and abiotic stresses and other agronomically important traits in cultivated brinjal varieties (Rotino et al., 2013). Surya, Swetha, Haritha and Neelima are some of the varieties suitable for Kerala. 
Global climate change is any significant long term change in expected patterns of weather over a region which may be naturally induced or anthropogenic. The major causes of this are increased industrialization, urbanization, deforestation, agriculture and change in land use patterns.

Climate is the primary determinant of agricultural productivity and crop production is vulnerable to the current state of climate variability because of anthropogenic global warming. The effect of climate change on crop and terrestrial food production are evident in several regions of the world. Negative impacts of climate trends have been more common than positive ones. For the major crops (wheat, rice and maize) in tropical and temperate regions, climate change without adaptation has negatively affected by increase in temperature, and resulted $25 \%$ of yield loss (IPCC AR5, 2014).

The productivity and quality of a crop attain its maximum potential when grown in an environment that is optimum for that particular plant species. Suitable and meaningful manipulation of environment is very important for sustainable agricultural development.

Growing the crops under a protected covering like greenhouses and rain shelter help to reduce evapotranspiration, moderate soil temperatures, reduce soil runoff and erosion, protect fruits from direct contact with soil and minimize weed growth. In controlled environmental practices or green house/ polyhouse cultivation, we can ensure optimum climatic condition in order to achieve maximum productivity.

Protected cultivation is a cropping technique through which the microclimate surrounding the plant is controlled partially or fully as per the requirement of plant species grown. Greenhouse, the latest word in Indian agriculture is one such means where the plants are grown under controlled or partially controlled environment resulting in high yield than that is possible under open cultivation.

Due to erratic behavior of weather, the crops grown in open fields are often exposed to fluctuating levels of temperature, humidity, wind flow and light which ultimately affect the crop productivity adversely. In this situation, protected cultivation is an attractive option to ensure quality production during all seasons.

\section{Materials and Methods}

The field experiments were conducted during February 2019 to April 2019 under two growing conditions namely, polyhouse and open field at the nursery located in Agricultural Research Station, Anakkyam, Malappuram district, Kerala. The site is located at $11^{\circ} 0.05^{\prime} 00.6^{\prime \prime} \mathrm{N}$ and $76^{\circ} 07^{\prime} 03.0^{\prime \prime} \mathrm{E}$ longitude and at an altitude of $47 \mathrm{~m}$ above MSL. The area experiences a typical warm humid climate and receives average annual rainfall of $2952 \mathrm{~mm}$. The soil of the experimental site comes under the textural class of typically lateritic and is acidic in reaction. The bacterial wilt resistant brinjal variety Haritha released by the Kerala Agricultural University was used for the study.

The crop was raised in grow bags arranged in both protected and open field at a spacing of $30 \times 30 \mathrm{~cm}$. The potting mixture was soil, sand and farmyard manure $(2: 1: 1)$ and one month old seedlings were transplanted in grow bags kept under two conditions. Urea, phosphorous and potash were applied to crops based on the package of practices by Kerala Agriculture University. Sucking pests were controlled using Beauveria bassiana $20 \mathrm{~g}$ /liter. Fruits were harvested after maturity and biometric parameters were recorded. 


\section{Abiotic factors}

Temperature and humidity were measured using digital thermometer and hygrometer from both open field and polyhouse at an interval of 2 hours. These two parameters were statistically analyzed in two factorial CRD. The first factor was environmental condition, at two different levels (polyhouse and open field) and the second factor was weeks at six different levels ( 27/02/2019 $05 / 03 / 2019, \quad 06 / 03 / 2019-12 / 03 / 2019$, $13 / 03 / 2019$ - 19/03/2019, 20/03/2019 $28 / 03 / 2019, \quad 29 / 03 / 2019-04 / 04 / 2019$, 05/04/0219 - 10/04/2019). So there were 12 different treatment combinations. The number of replications was four. Soil moisture per cent was also observed from both open field and polyhouse conditions using standard procedure of gravimetric method, using the formula,

Percentage soil moisture $=$ Weight of moist soil (M) - Weight of dry soil (D) Weight of dry soil (D)

\section{Biometric observations}

Plant height and number of leaves per plant were recorded at weekly intervals starting from the day of transplanting. These two biometric characters were statistically analyzed in two factorial CRD. The first factor was environmental condition, at two different levels (polyhouse and open field) and the second factor was weeks at seven different levels (27/02/2019 - 05/03/2019, $06 / 03 / 2019$ - 12/03/2019, 13/03/2019 $19 / 03 / 2019, \quad 20 / 03 / 2019-28 / 03 / 2019$, 20/03/2019 - 28/03/2019, 04/04/0219 $9 / 04 / 2019,10 / 04 / 2019$ - 15/04/2019). So there were 14 different treatment combinations. The number of replications was five.

Leaf area index was also measured from both conditions. Leaf area index was statistically analyzed in two factorial CRD. The first factor was environmental condition, at two different levels (polyhouse and open field) and the second factor was weeks at three different levels (27/02/2019 - 12/03/2019, 13/03/2019 - 28/03/2019, 29/03/2019 $10 / 04 / 2019$ ). So there were six different treatment combinations. The number of replications was five. Fruit characters like fruit length, girth, and weight were measured and recorded from open field and polyhouse.

\section{Results and Discussion}

\section{Abiotic factors}

Temperature recorded was maximum under polyhouse as compared to open field (Fig. 1). This is in confirmation with the findings of Ajithkumar (1999). Anbarasan (2002) observed that high temperature under polyhouse increases fruit size and productivity. Mean weekly temperature during summer and winter season were higher under polyhouse than open field. The higher temperature favourable for increase in plant length, number of branches, intermodal length, average fruit weight and yield per plant were higher inside the polyhouse (Rajasekar et al., 2013).

Humidity was recorded high under polyhouse as compared to open field (Fig. 2). Nimje and Shyam (1993) observed that the relative humidity was higher inside the green house than in open field, which influenced tomato growth and yield.

Anbarasan (2002) observed that high humidity under polyhouse increased fruit size and productivity in tomato. The soil moisture content were more in crops under polyhouse as compared to open field condition. This is in conformity with the findings of Kayssi et al., (1990). 


\section{Biometric observations}

There was significant variation in plant height with respect to different growing conditions and weeks (Table. 1). Increased plant height was observed under polyhouse as compared to open field. This is in conformity with the findings of Safia (2010) and Lal et al., (1991).

In the present study, there was significant variation in number of leaves per plant with respect to growing medium and weeks (Table. 2). Highest number of leaves per plant was observed under polyhouse as compared to open field. Prabhu et al., (2009) have observed that plant height and leaf production were maximum under shade net cover. Leaf area index varied significantly among different growing medium and weeks (Table. 3 ). Increased leaf area index observed under polyhouse growing condition as compared to open field growing condition.

Leaf area index was significantly influenced by growing conditions. Crops grown under polyhouse have maximum mean for leaf area index. The higher LAI under polyhouse may be due to high temperature (Anbarasan, 2002). Mean fruit length $(23.8 \mathrm{~cm})$, girth $(13$ $\mathrm{cm})$ and fruit weight (106.6 g) were higher under polyhouse as compared to open field $(20 \mathrm{~cm}, 12 \mathrm{~cm}$ respectively and $(78.32 \mathrm{~g})$.

Table.1 Effect of environmental conditions, weeks and their interactions on plant height

\begin{tabular}{|c|c|c|c|c|c|c|c|c|}
\hline & W1 & W2 & W3 & W4 & W5 & W6 & W7 & $\begin{array}{c}\text { Mean } \\
\text { (Environmental } \\
\text { condition) }\end{array}$ \\
\hline E1 & 6.400 & 6.540 & 8.100 & 9.300 & 18.900 & 26.500 & 44.400 & 17.163 \\
\hline $\mathbf{E 2}$ & 6.000 & 6.060 & 6.620 & 7.700 & 10.600 & 14.600 & 20.000 & 10.226 \\
\hline $\begin{array}{l}\text { Mean } \\
\text { (Weeks) }\end{array}$ & 6.200 & 6.300 & 7.360 & 8.500 & 14.750 & 20.550 & 32.200 & \\
\hline \multicolumn{3}{|c|}{$\begin{array}{l}\text { CD (E) - 1.415 } \\
\text { W1- 27/02/2019-05/03/2019 } \\
\text { W2- 06/03/2019-12/03/2019 } \\
\text { W3 - 13/03/2019-19/03/2019 } \\
\text { W4-20/03/2019- } 28 / 03 / 2019\end{array}$} & \multicolumn{5}{|c|}{$\begin{array}{ll}\text { CD (W) }-2.648 & \text { CD (E×W)-3.745 } \\
\text { W5 }-29 / 03 / 2019-03 / 04 / 2019 & \end{array}$} & \\
\hline
\end{tabular}

Table.2 Effect of environmental conditions, weeks and their interactions on number of leaves

\begin{tabular}{|c|c|c|c|c|c|c|c|c|}
\hline & W1 & W2 & W3 & W4 & W5 & W6 & W7 & $\begin{array}{c}\text { Mean } \\
\text { (Environmental } \\
\text { conditions) }\end{array}$ \\
\hline E1 & 5.200 & 4.800 & 4.200 & 6.400 & 9.600 & 14.400 & 23.800 & 9.771 \\
\hline E2 & 5.200 & 3.800 & 4.000 & 5.200 & 6.800 & 7.600 & 14.400 & 6.714 \\
\hline $\begin{array}{l}\text { Mean } \\
\text { (Weeks) }\end{array}$ & 5.200 & 4.300 & 4.100 & 5.800 & 8.200 & 11.000 & 19.100 & \\
\hline $\begin{array}{l}-1.362 \\
0.02 / 2019-( \\
03 / 2019-1 \\
3 / 03 / 2019- \\
0 / 03 / 2019\end{array}$ & $\begin{array}{l}\text { /03/2019 } \\
\text { 103/2019 } \\
9 / 03 / 2019 \\
\text { /03/2019 }\end{array}$ & & $\begin{array}{l}\text { CD } \\
\text { W5 } \\
\text { W6 } \\
\text { W7 } \\
\text { E1 }\end{array}$ & $\begin{array}{l}\text { W) }-2.54 \\
29 / 03 / 21 \\
04 / 04 / 02 \\
10 / 04 / 2 \\
\text { Oolyhous }\end{array}$ & $\begin{array}{l}9-03 / 0 \\
9-9 / 04 / \\
19-15 / 0\end{array}$ & $\begin{array}{l}12019 \\
2019 \\
4 / 2019\end{array}$ & $(\mathrm{E} \times \mathrm{W})-3$ & \\
\hline
\end{tabular}


Table.3 Effect of environmental conditions, week and their interactions on leaf area index

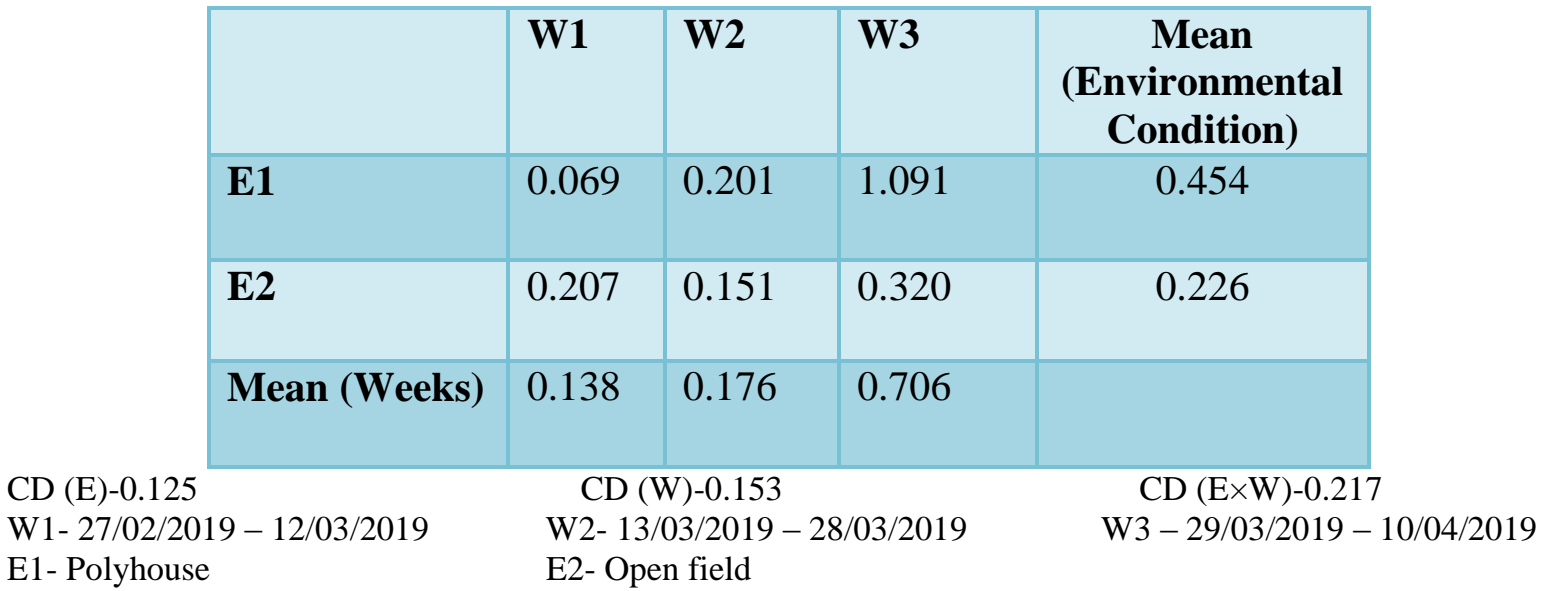

Table.4 Mean fruit length, girth and weight under different environmental conditions

\begin{tabular}{|l|c|c|c|}
\hline $\begin{array}{l}\text { Environmental } \\
\text { conditions }\end{array}$ & $\begin{array}{c}\text { Mean fruit length } \\
(\mathbf{c m})\end{array}$ & Mean fruit girth(cm) & Mean fruit weight (g) \\
\hline E1 & 23.800 & 13.500 & 106.64 \\
\hline E2 & 20.000 & 12.000 & 78.32 \\
\hline
\end{tabular}

E1 - Polyhouse; E2- Open field

Fig.1 Periodical variation in temperature under different environment conditions

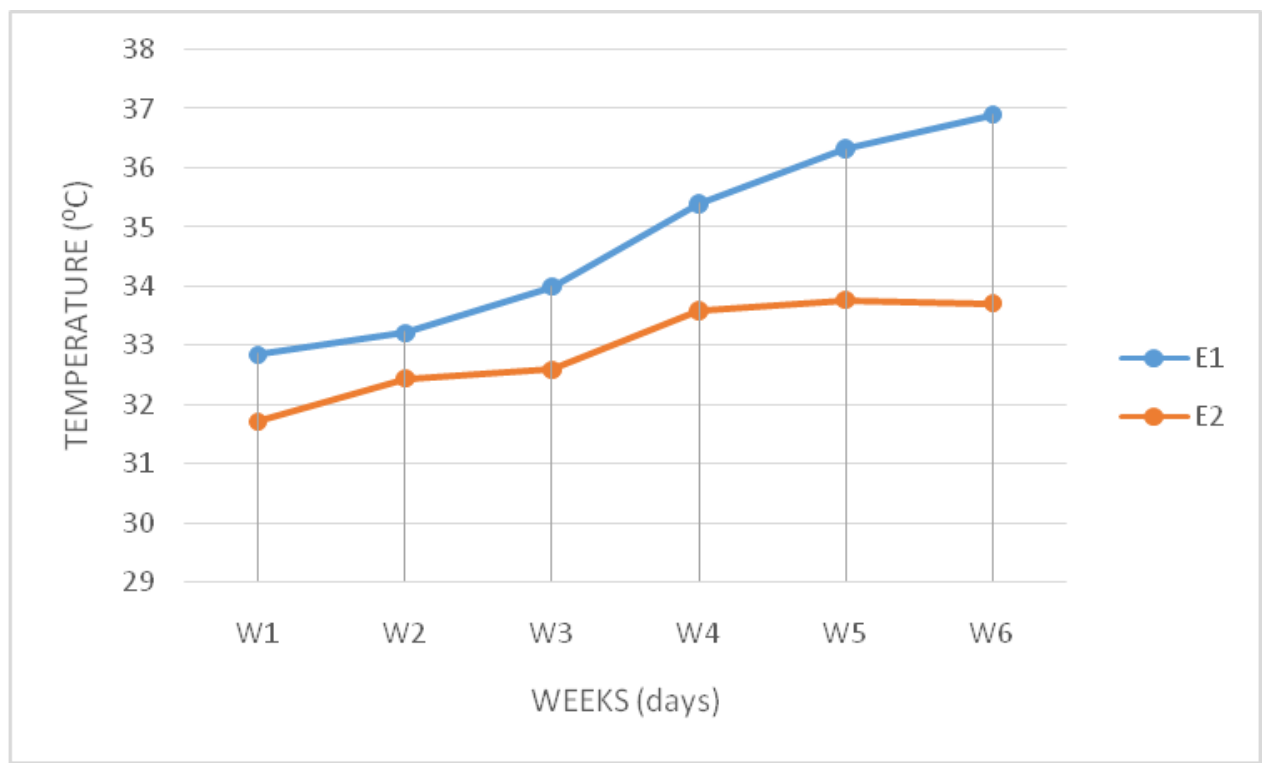

W1- 27/02/2019-05/03/2019

W2- 06/03/2019 - 12/03/2019

W3 - 13/03/2019 - 19/03/2019

E1 - Polyhouse;
W4 - 20/03/2019 - 28/03/2019

W5 - 29/03/2019-04/04/2019

W6 - 05/04/0219 - 10/04/2019

E2- Open field 
Fig.2 Periodical variation in humidity under different environment conditions

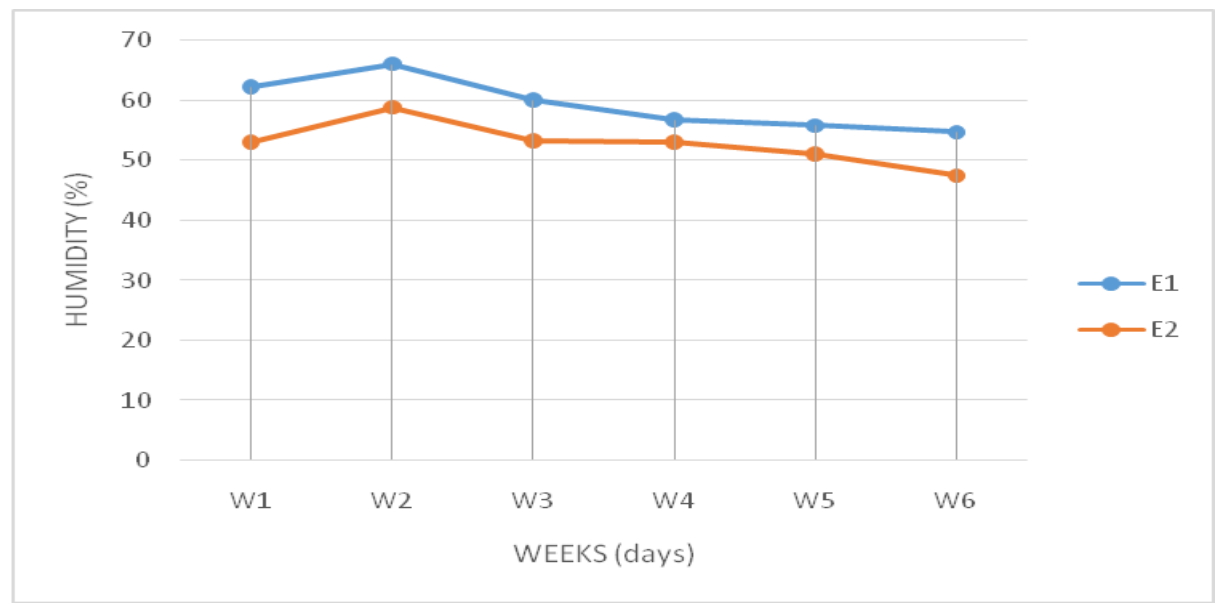
W1 - 27/02/2019-05/03/2019
W2- 06/03/2019-12/03/2019
W3 - 13/03/2019-19/03/2019
E1 - Polyhouse
W4 - 20/03/2019 - 28/03/2019
W5 - 29/03/2019-04/04/2019
W6 - 05/04/0219 - 10/04/2019
E2- Open field

Fig.3 Mean soil moisture content under different environmental conditions

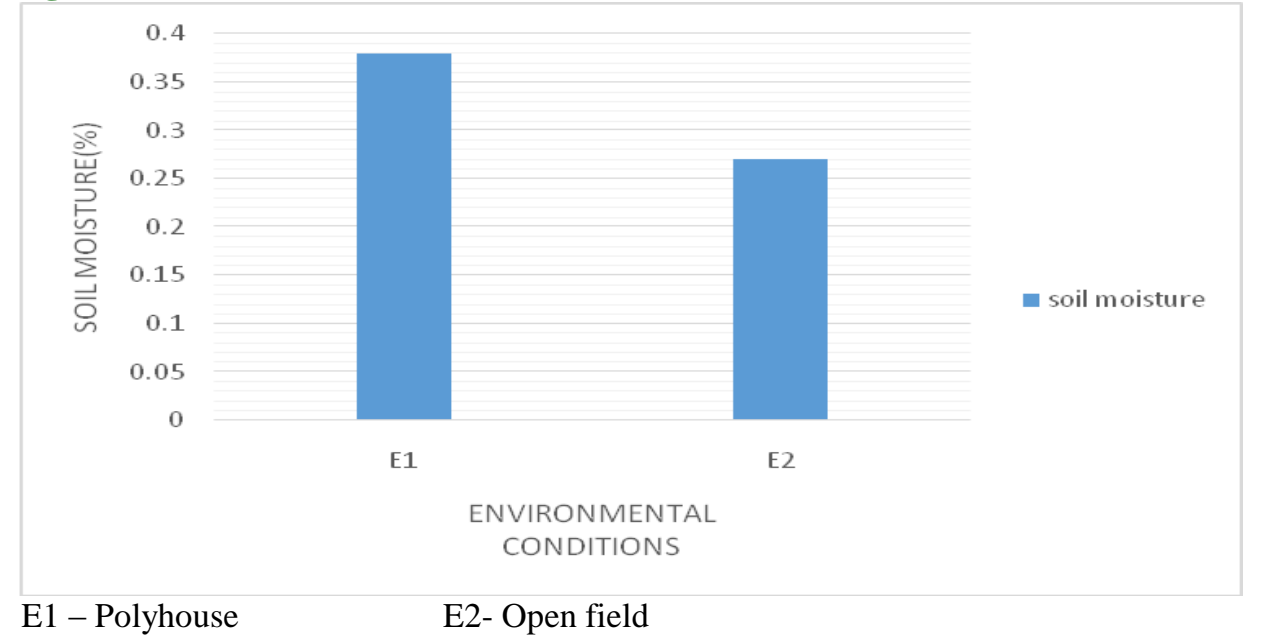

In the present study there was significant variation in fruit length obtained from polyhouse and open field. Length of fruit was higher under polyhouse as compared to open field (Table. 4). According to Pinturoy (2014), higher number of fruits with maximum length and weight were obtained from chilli plant growing under polyhouse.

The mean fruit girth obtained from crops under polyhouse and open field varied significantly. Fruit girth under polyhouse was higher and as compared open field (Table. 4). According to Ranag et al., (2014) higher number of fruits (38) with maximum length (4.4) and diameter (5.4) and weight (68) in tomato were observed under polyhouse.

The mean fruit weight was higher under polyhouse as compared to open field (Table. 4). This is in conformity with the findings of Anbarasan (2002) and Pinturoy (2014). 
Reddy et al., (2006) observed that the average size and weight of sweet pepper was higher under greenhouse than open field.).

\section{Acknowledgment}

The authors are thankful to Kerala Agricultural University and The Department of Environmental science, University of Calicut for providing the technical facilities and financial assistance. Also express their gratitude to Dr. C.C Harilal, Dr. Rathy M.C, Dr. Leya Thomas, and Dr. T. R.Shanthi, University of Calicut for their valuable suggestions.

\section{References}

Ajithkumar, B. 1999. Crop weather relationships in tomato (Lycopersicon esculentum) (Doctoral dissertation, Department of Olericulture, College of Horticulture, Vellanikkara).

Anbarasan, S. (2002). Productivity of tomato in relation to seasons and growing conditions (Doctoral dissertation, Department of Olericulture, College of Horticulture, Vellanikkara).

AW Al-Kayssi, AA Al-Karaghouli, AM Hasson, 1990. Elsevier influence of soil moisture content on soil temperature and heat storage under greenhouse conditions. Journal of Agricultural.

IPCC, (2013): Stocker, T. F., Qin, D., Plattner, G. K., Tignor, M., Allen, S. K., Boschung, J. and Midgley, P. M. (2013). Climate change 2013: The physical science basis.

Lal, G., Singh, D.K. and Tiwari, R.P. (1991). Performance of some tomato cultivars during summer in Tarai region. Veg. Sci. 18: 99- 101

Muthuvel, I., Thamburaj, S., Veeraragavathatham, D. and Kanthaswamy, V. (2000). Performance of tomato genotypes under normal season and high temperature simulated glasshouse condition. S. Indian Hort., 48: 96-99.

Nimje, P. M. and Shyam, N. (1991). Greenhouse as an alternative technology for commercial vegetable crop production. Indian J. Agric. Sci. 61: pp.185189.

Pinturoy, V. (2014). Production technology of Chilli (Capsicum annum L.) under protected cultivation (Doctoral dissertation, College of Agriculture, Vellayani).

Prabhu, M., Kumar, A. R., Balasubramanian, V., Jagadeesan, R. and Ponnuswami, V. (2009). Protected cultivation of vegetables. Asian J. Hortic. 4 (2): pp.529-533.

Rajasekar, M., Arumugam, and Kumar, R. S. (2013). Influence of weather and growing environment on vegetable growth and yield. J. Hort and forestry. Vol. 5 (10), Pp. 160-167.

Reddy, E. S. G. and Kumar, K. K. N. (2006). A comparison on management of thrips, Scirtothrips dorsalis Hood on Sweet pepper grown under protected and openfield cultivation. S.Indian Hort. 12: 45-54.

Rotino, G. L., Sala, L., Toppino. (2013). Eggplant. Alien Gene Transfer in Crop Plants, Volume 2, 381-409.

Safia, M. (2015). Modelling the impact of climate change on growth and yield of tomato. Msc (Agri) thesis, Kerala Agriculture University, Thrissur, Kerala, $140 p$.

\section{How to cite this article:}

Shikha. E., M. Kunnathadi, K. Shahida, S. Sreelekshmi and Jubail. E. 2020. Assessment of Environmental Factors on Growth of Brinjal under Open and Protected Conditions. Int.J.Curr.Microbiol.App.Sci. 9(04): 380-386. doi: https://doi.org/10.20546/ijcmas.2020.904.045 